\title{
Small-Scale Business Leadership in Ethiopia: An Assessment of Financial Bureau Opportunities in Yayu Woreda
}

http://doi.org/10.21272/bel.5(2).122-138.2021

Satya Narayan Singh, ORCID: https://orcid.org/0000-0002-1494-4489

Dr, Associate Professor, Department of Economics, Faculty of Business and Economics, Mettu University, Ethiopia

\begin{abstract}
The present research paper highlights small-scale business leadership in Ethiopia to assess the financial bureau in Yayu Woreda of Ilu Abba Bora Zone of Oromia regional state of Ethiopia. The other allied purpose relates to evaluating the budgetary performance of the Yayo Woreda finance office in the Ilu Abba Bora Zone. The sampling technique is based on simple random sampling, and scientifically there were 100 samples of respondents taken from approximately one thousand and three hundred and seventy-three employees in the woreda. The representative samples were included one head office person, the council head of the budget and finance committee, plus the committee members from the Audit Office, Auditor general, deputy auditor general, Audit manager, and the audit team of consolidated financial statements. Additionally, three employees were also included from each sector, such as planners, accountants, and internal auditors, to control appropriate utilization of limited resources and auditing performance for the allocated budget at the woreda finance office. The descriptive survey design was employed in this study, and appropriate data collection methods were used through questionnaires and interviews. However, the secondary data is extracted from the final report and oversight of the written books and brochures. The data were analyzed and interpreted while using an appropriate methodology of concurrent concern. The study established that the budget implementation and its performance have a negative relationship to some extent. It is recommended that the woreda hai to enhance its manpower, particularly in the budget process, to improve budgetary performance, particularly in the aspect of small-scale business leadership.
\end{abstract}

Keywords: Budget Process, Budgetary Performance, Financial Bureau, Performance Audit, Small-Scale Business Leadership.

JEL Classification: G20, G21, G23.

Cite as: Singh, S.N. (2021). Small-Scale Business Leadership in Ethiopia: An Assessment of Financial Bureau Opportunities in Yayu Woreda. Business Ethics and Leadership, 5(2), 122-138. http://doi.org/10.21272/bel.5(2).122-138.2021.

Received: 09 May $2021 \quad$ Accepted: 15 June $2021 \quad$ Published: 25 June 2021

Copyright: (C) 2021 by the author. Licensee Sumy State University, Ukraine. This article is an open access article distributed under the terms and conditions of the Creative Commons Attribution (CC BY) license (https://creativecommons.org/licenses/by/4.0/).

\section{Introduction}

1.1 Background of the Study. Throughout the world, various studies describe the budgetary performance in different countries, including African countries, since the study of M. Isaboke (2016) illustrates that financial performance is a subjective measure of using assets from its primary means of business and create revenues. Another study of Anderson (2011) highlighted the importance of financial stability that enables an organization to have sufficient resources for quality service delivery and safeguard good credit risk. This belief makes financial performance an essential area of attributes that attracted researchers, government, and policymakers. However, for several years, there have been reported cases of budget inappropriately accomplishment, budget disparity, budget indiscipline, poor or non-performance of budget, and poor budgetary implementation. Moreover, it is also recognized that many countries cannot achieve their planned targets efficiently despite having a sound budgetary provisional system. Therefore, it is anticipated that the rules of the game by which the budget is formulated and implemented are equally important, and they are effectively influencing outcomes (Felix Olurankinse, 2013). Funding is basically used to prepare plans on how to go about its future operations and as a way of assessing the performance of the office of finance and economic development through making comparisons of actual results against budgeted results (Elias Hailmeskel, 2018). 
Therefore, the critical challenge and controversial issues related to public budgeting are reflected in the budget preparation, approval, implementation and controlling stage of the budget cycle. The responsibility of the manager has become more important in the case of budgeting and control systems and furthermore, business budgeting is an essential process that allows businesses to gain many opportunities while acting only one course of action. During budget plan and implementation, there were many numerous goals that the business operators expect. As indicated by Elias Hailmeskel's (2018) study, a budget is a document or financial plan of any organization, be it government, nongovernment, or private institutions. There are different ways of budget management practiced by the different types of organizations. Central budget is proposed to realize the national objectives, goals, and programs linked to the role of government or public institutions in financial matters. On the other hand, according to Kariuki (2010), budgeting is a process of planning the financial operations of a business and budgeting is a management tool that helps organize planning activities of management. According to the study of Niyonsaba SPES (2014), budget is the cornerstone for organizational effectiveness and efficiency; it involves careful planning, awareness of the environment and alignment with the organization's short and long-term strategies. The proper budgeting facilitates management oversight by proving a base to monitor how resources are used efficiently in the long-term strategic objectives of an organization without losing its control and accountability mechanisms. However, modern budgeting may be of better support to performance management integrated with analysis of performance trends.

However, the budgetary performance of the Finance office faces many problems such as budget deficit, unequal distribution of budget between each Sector. Hence, there should be a fascinating effort to minimize the budget deficit (Felix Olurankinse, 2013). On the other hand, each year, there is an inventory evaluation process taken up regularly. According to the growth of the Sector's office, it was not fully recorded and not taken to the extent as a means of budget utilization. Most of the time, the budget deficit should be controlled by the finance office and by the periodical performance of the Sector. According to this case, there is a gap created in the Finance office system that affects the sector's goal. The sector performance differs from one Sector to another, but all need adequate budgetary performance management. Assessment of budgetary performance was consistent with the finance office to utilize the planned budget. Generally, now a day every business is required budgetary performance, it should be available resources would be employed and what additional resource would be needed.

1.2 Statement of Problem. The finance office of the woreda always prepares the annual budget for current year activities by the designed budget proposal and its active implementation of objectives. Budget is one of the techniques used to control the woreda's sectors activities in quantitative expression to set the period with the proposed plan of action by management. According to Bartle (2001), the budget terminology was initially introduced in the 1920s as a tool to manage costs and cash flows in large industrial organizations. In the early stage of development, budgeting was concerned with only preparing and presenting authentic information to legitimize accountability (Hindereth, 2002). In the emergence of scientific management, the philosophy laid more emphasis on detailed information for making accurate decisions that paved the platform for the tremendous development of management accounting and budgeting techniques (Bartle, 2008). According to Bartle (2008), budgets today provide a focus for the organization, aid in coordinating activities and facilitate control (Bartle, 2001). However, the mechanism of budgeting, at both level of management and operation, it lays down the foundation of what must be achieved, control, checks soon.

Budget is the formal expression of the plan and objective of management to the organization, which covers all phases of operations for a specific period (Esayas Abshiro et al., 2014). Good budgetary performance can be a vehicle for addressing objectives and goals in the most careful way. Still, in preparing the budget, many problems were taking place, and consequences create an impact on the organization's performance. Consequently, budget is increasingly recognized as the key tool for economic management. The government budgetary process is a deliberate and systematic attempt to allocate public resources to various ministries and departments to finance activities and programs within their specific mandates (Kirira N., 2002). The common problems encountered inappropriate budget preparation procedures \& not well utilization of budget for each department within the organization (Felix Olurankinse, 2013). Moreover, the budgeting problem is not only at the preparation stage but also at the implementation stage. According to Suraj Kumar (2011), a budget is based on estimates; it may or may not be true. It is not deputy of management because the efficiency and utility of the budgetary system depend on the skill and experience of the management. It cannot be executed routinely because continuous efforts are necessary for the execution of the budget.

This problem of budgetary performance was the event tangibly seen in the finance office of Yayu Woreda as each year's final report was indicating the implementation of each government sector's performance. If the 
problem is boldly seen in the woreda as far as we know, nobody has been conducted a study concerning it. Therefore, the concern of this study is to examine the assessment of budgetary performance in a particular area of Yayu Woreda finance Office in Ilu Aba BorZone. The research primarily focuses on the finance office as it is the source of all sectors to give the final solution and suggestion to the problems. To achieve the intended purpose of the study, the researcher formulated the following fundamental research questions:

$>$ What are the factors affecting small scale business leadership in Ethiopia?

$>$ How is the budgetary performance associated with leadership?

$>$ How to assess budget implementation in Yayu Finance Office?

What are the measures are being used by the Finance Office to prepare a good budget system?

1.3 Objective of the Study. The general objective of the study is to assess the factors affecting small scale business leadership and its association with budgetary performance. The specific objectives of the study are:

To unveil the factors affecting more budgetary performance of the woreda.

To identify the importance of budgetary performance.

To examine whether the organization effectively implements its budget or not.

To identify the different methods that the Finance office uses to prepare an excellent budgetary System.

1.4 Significance of the Study. This study helped the finance office have an excellent budgetary practice, properly budget the available resources, and effectively implement it. In addition, the study will be used to provide groundline information for the organization's advancement to provide a better service. The study also will help to examine the factor affecting budgetary performance in the finance office. Furthermore, it helps to identify ways and means by which the office's budgetary performance is improvised to the best level expectation. Above all, the study will help decision-makers take valid and effective measures in managing budgetary performance in an organization and avoid the problem associated with budget using activities. The study will also form a base for other researchers to conduct further studies in the area which has not been covered. To come up with practical and better analysis 'would have better if the survey were conducted on overall organization performance than other similar office performance. This study was conducted only in the Yayu woreda finance office from the fourteen woredas of the zone. Therefore, the study is only limited to the study unit. 100 Employees of the woreda with the finance office employees were in the study. The time horizon of the study covered by this research had been limited to assess the last seven years budgetary performance of Yayu woreda Administration Finance Office covering from 2006 up to 2012 E.C (Ethiopian Calendar). In the previous seven years, a budgetary performance trend of the Finance is observed from seven years audited budget report of Yayu woreda Finance Office.

\section{Research Methodology}

This part presents the description of the study area, research design and methodology. It includes sources of data, sample and sampling technique, data gathering instruments, data gathering produces and data analysis techniques and Ethical Consideration.

2.1 Description of the Study Area. Yayu woreda is found in the Eastern part of Ilu Aba Bor Zone. The woreda was located $566 \mathrm{kms}$ far from the capital city of Ethiopia, Addis Ababa, in the southwest direction. The study area is situated in the geographic coordinates between $7058^{\prime} 30^{\prime \prime}$ to $808^{\prime} 30^{\prime} \mathrm{N}$ latitudes and $35028^{\prime} 30^{\prime \prime}$ to 35033'30"E longitudes (EMA, 1988). According to the data gathered from Ilu Aba Bor Zone Agriculture and Natural resource office, the altitude of Yayu Woreda ranges from 1630 a.s.l, and its agro ecologic zone is shared into 9.623\% Dega,46.76\% Weina Dega and $43.617 \%$ desert. Its temperature and rainfall respectively range from $18 \mathrm{co}-24 \mathrm{co}$ and $1150 \mathrm{~mm}-2200 \mathrm{~mm}$. The area was mostly known for producing different crops like corn, Sorghum, coffee, spices, etc. The weather conditions of these area are even not suitable to produce different crops. The total population of Yayu woreda is estimated to be76817. Among these, 38379 are males, and 38438 are females, according to population and housing census reports (CSA, 2007). According to the same source, the total number of households in the woreda is 13456households with an average family size of 5.7 persons per household. The population of the area is the best known by facilitating different infrastructures like school, road and health service, etc. The number of populations increases from year to year in the organization that causes migration to the abroad (Finance Office of Yayu Woreda (2011/012)).

2.2 Research Intention and Design. Research intention and design include one of the important notations to prepare the roadmap of conducting the entire study. Therefore, this study aims to assess budgetary performance and point out the challenges encounter. Also, in this study descriptive survey design was employed. As Kothari (2008) asserted, a descriptive survey enables to respond to the - what question, which is the case in this study. 
The surveying aspect was since the study was conducted at a specific point in time, and the respondents cut across different departments. The research focuses mainly on describing, analyzing and interpreting the conditions that exist in relation to budgetary performance in the Woreda.

2.3 Data Types and Source. For gathering more accurate information, both primary and secondary sources of data have been used systematically. However, the primary data were gathered from employees of the organization by distributing questionnaires and interviews through related parties. The questionnaires contain both open-end and close-end questions. The interview will be conducted by direct communication with the finance managers /head office person. Secondary Source of data were collected from review of selected materials which are related to the assessment of budgetary performance, like reference book magazines used interned and the organization budget report document.

2.4 Target Population. The target respondents used by the researcher were current employees in different sectors and the heed office of the Yayu finance Office. With this context, the population of this study is professional employees of Finance and other concerned bodies. According to the information from the woreda administration, there are about 1337 employees in the woreda. Though incorporating all employees' ideas on the analysis would have been better for conclusion and generalization, economically and operationally, it was complicated to contact all employees in the research. Therefore, taking a representative sample of the population of the employees was found to be feasible.

2.5 Sampling Techniques. A researcher carried out the sample selection. So, it is reliable to represent the total population who are believed high civil servants to the Finance Office and other sectors. Therefore, the research focuses on the employee of the woreda by using simple random sampling techniques to acquire the necessary information and make clear investigations for the current research. The total population of the study is including 1373 employees with one head office. Out of these, researchers randomly selected 100 employees as a sample and taking this into account on factors, it is found necessary to use personal judgment.

2.6 Sample Size. The employees who have been currently working from the Finance Office and other sectors were involved as respondents in the study because they enabled the researcher to collect primary information regarding the budgetary performance. Therefore, the respondents that were used were the current employees in the woreda and the head office of the Yayu Finance office. To undertake the study, the researcher needed an adequate sampling size to collect relevant information and efficiently and effectively undertake the research. Sample were selected from different strata including council head of budget, finance committee and the committee members, Auditor general, deputy auditor general, Audit manager and the audit team were taken into consideration. Moreover, three employees from each sector such as planners, accountants, and internal auditors of finance office as well as one head office of Finance office in woreda were taken in sample size selection. To conduct the study, the researcher selected a total population of current employees in the woreda and determined about 100 representatives of samples out of 1373 of current total employees in the woreda. The scientific formula was used to decide the sample size for the study as.

$\mathrm{n}=\mathrm{N} / 1+\mathrm{N}(\mathrm{e})^{2}$

where, $\mathrm{N}=$ total population

$\mathrm{n}=1373 / 1+1373(0.1)^{2}=99.93 \approx 100$

$\mathrm{n}=$ sample size

$\mathrm{e}=$ error terms

2.7 Method of Data Analysis. In this study, the data were analyzed and interpreted using different methods. The method includes tabulation and percentage. Tabulation is used to arrange data in a table or other summary format to compare various data analyses. Furthermore, collected data were analyzed by using both descriptive and inferential statistics while using SPSS. The descriptive analysis involved frequencies and percentages for demographic data of respondents.

2.8 Ethical Considerations. The current study was subjected to specific ethical issues. All participants were required to report their written acceptance regarding their participation in the research through a signed consent and briefing letter. At the same time, sample members were asked to sign a debriefing and withdrawal letter. Both letters aimed to reassure participants that their participation in the research is voluntary and that they would free to withdraw from it at any point and for any reason. Next to this, participants were fully informed regarding the study's objectives. At the same time, they would reassure that their answers were treated as confidential and used only for academic purposes and only for the research. Except for the above, participants 
will not be harmed or abused physically and psychologically during the study. The researcher attempted to create and maintain a time of comfort for them.

\section{Result and Discussion}

3.1. General Overview. In this part, the data collected from various sources related to the budgetary performance of the Yayu Woreda Finance Office have been discussed. The researcher focuses on data analysis and presentation about a study on assessment on budgetary performance in Growth and Transformation Plan (GTP) of the woreda Finance Office. The data presentation and analysis of the data collected from both primary and secondary sources were analyzed using themes from research questions and objectives. The raw data collected from employees, officials, and secondary data sources were categorized, edited, organized, and analyzed using quantitative and qualitative methods. The quantitative data were converted into relevant information using analysis of ratios, frequencies, and percentage; and presented in tables and figures mainly to support the qualitative descriptions.

3.2. Response Rate. As it has been clearly shown in the methodology part of the study, the total sample of the target population was one hundred (100). Based on this, the researcher has distributed the questionnaires related to the integration of planning and budgeting, the mismatching of budget and planning, implementation and control \& performance auditing for allocated budget from the Yayo Finance office. For maintaining accuracy, the data were collected from different sources of strata like council head of budget, finance committee and the committee members, Auditor general, Deputy Auditor general, Audit manager and the audit team of the consolidated financial statements etc. Moreover, three employees from each sector of planner, accountants and internal auditors were also considered. The questionnaires were prepared containing 22 questions including closed and open-ended, and distributed randomly to one hundred (100) target people. Consequently, only seventy three out of hundred (73\%) of the respondents, which are $42(57.53 \%)$ males and $31(42.47 \%)$ females, filled the questionnaires correctly and returned to the researcher and remaining twentyseven $(27 \%)$ questioners were rejected or out of use. Since these number of respondents were partially filled or not willing to be filled and return the questionnaire to the researcher.

3.3. Demographic Profile of Respondents. The demographic profile of respondents is presented in terms of general characteristics such as age, gender, education level, work experience, etc. are being considered as socio-demographics and are being asked in all kinds of surveys.

\subsubsection{Gender Composition of the Respondents}

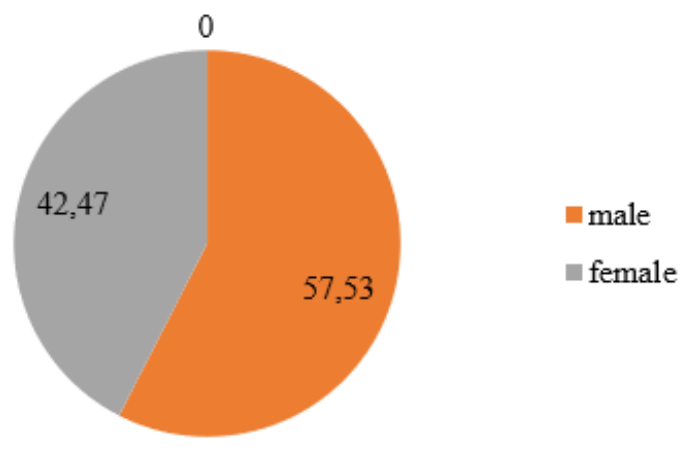

Figure 1.1 Gender Compositions of Respondents

Source: Primary Survey (2020)

3.3.2 Educational Level of Respondents. The respondents of this study education level are shown below in fig. 1.2, most of the respondents that is $65(89.04 \%)$ of them are first degree holders, 2 (2.74\%) respondents were certificates, while $6(8.22 \%)$ are master's degree and above. Therefore, since the education level relates to the profession and, we can assume that the information provided by the respondents were valid and reliable. 


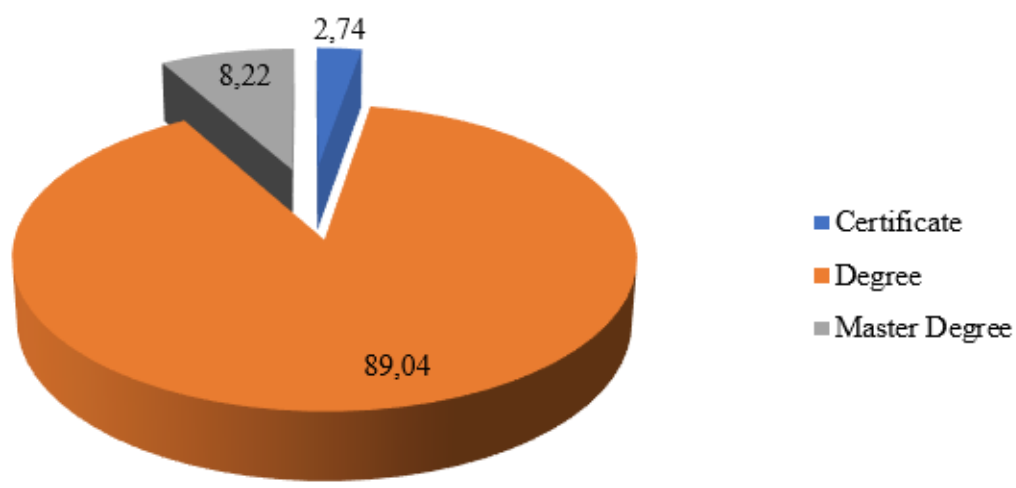

Figure 1.2 Education Level of Respondents

Source: Primary survey (2020)

3.3.3 Work Experience of the Respondents. The work experience of the respondents in the current study shows that 7 (9.59\%) of them have work experience of fewer than five years, 14.18 (39\%) of the respondents have work experience of in between 6-10 years, whereas 34 (46.57\%) of the respondents have work experience in between 11-15 years. Finally, the other 18 (24.66\%) of the respondent has work experience above 16 years. Therefore, as shown in the figure, the respondents' work experiences were mainly between 11-15 years with $46.57 \%$. It may have a positive impact on the total activity of the Yayu woreda Finance office because as they have a lot of work experience, they know very well rather than those who have 6-10 years' work experience relatively and the others. As a result, they easily understand the questioners and fill the appropriate answers concerning budget integration with plan appropriation and actual budgetary performance.

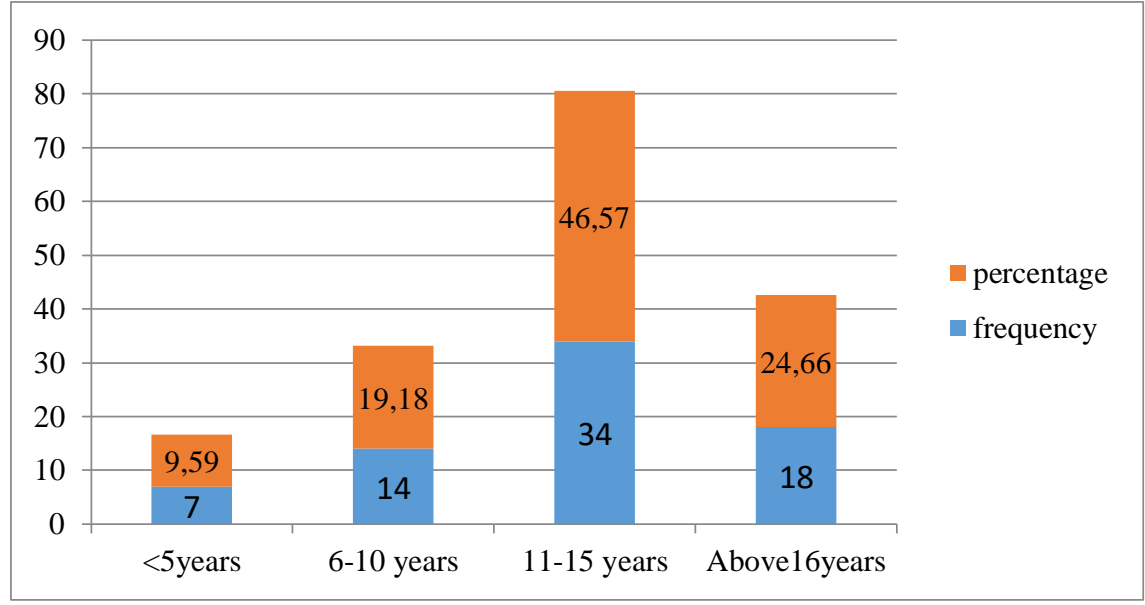

Figure 1.3 Work Experience of the Respondents

Source: Primary Survey (2020)

4.4 The Factors Affecting Budgetary Performance of the Finance Office. To identify the factors affecting budgetary performance of the Yayu Wreda Finance Office and some questioners were prepared and distributed to the respondents and the response of respondents analyzed and organized as follow.

4.4.1 Integration of Planning and Budgeting. Integrated planning supports strategic decision-making by providing a comprehensive view of resources and commitments that ensure financial and capital resources with academic priorities. Proceeding to adopt integrated planning, bitty planning activities occurred across the Woreda. Therefore, the woreda of finance office requires line agencies to define their mission, objectives, and activities and link expenditure to performance measures in terms of outputs and outcomes. To know the fact whether there is an integration between planning and budgeting in the Finance Office of Yayu woreda or not. The objective of budget in principle, let us see the response of the sample planer and budget holders in integration to plan and budget preparation to know whether these are affecting the budgetary performance of the woreda or not.

Therefore, four (4) questions were forwarded on the beginning part of the integration of budget with plan and budget requested. 
Table 1.1 Integration of Planning and Budgeting

\begin{tabular}{|c|c|c|c|c|c|c|c|c|}
\hline № & Questions & 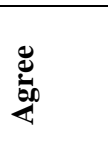 & 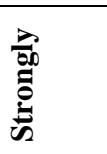 & Z & 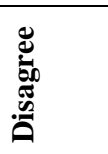 & 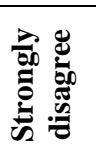 & 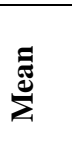 & के \\
\hline 1 & $\begin{array}{l}\text { Medium term expenditure Framework } \\
((\text { MTEFs })) \text { is prepared in each spending } \\
\text { agency }\end{array}$ & $\begin{array}{c}30 \\
41.1 \%\end{array}$ & $\begin{array}{c}12 \\
16.4 \%\end{array}$ & $\begin{array}{c}8 \\
10.9 \%\end{array}$ & $\begin{array}{c}17 \\
23.3 \%\end{array}$ & $\begin{array}{c}6 \\
8.2 \%\end{array}$ & 2.8 & 1.16 \\
\hline 2 & $\begin{array}{l}\text { The Office has mechanism to link the annual } \\
\text { budget proposal with the physical plans of } \\
\text { budgetary institutions. }\end{array}$ & $\begin{array}{c}29 \\
39.7 \%\end{array}$ & $\begin{array}{c}9 \\
12.3 \%\end{array}$ & $\begin{array}{c}8 \\
10.9 \%\end{array}$ & $\begin{array}{c}25 \\
34.2 \%\end{array}$ & $\begin{array}{c}2 \\
2.7 \%\end{array}$ & 2.4 & 1.08 \\
\hline 3 & $\begin{array}{l}\text { There is strong relationship between project } \\
\text { planning and formulation of capital budget in } \\
\text { every spending agency }\end{array}$ & $\begin{array}{c}27 \\
37 \%\end{array}$ & $\begin{array}{c}9 \\
12.3 \%\end{array}$ & $\begin{array}{c}9 \\
12.3 \%\end{array}$ & $\begin{array}{c}28 \\
38.3 \%\end{array}$ & $\begin{array}{c}0 \\
0 \%\end{array}$ & 2.9 & 1.31 \\
\hline 4 & $\begin{array}{l}\text { You have adequate understanding to prepare } \\
\text { plan and budget }\end{array}$ & $\begin{array}{c}33 \\
45.2 \% \\
\end{array}$ & $\begin{array}{c}14 \\
19.2 \% \\
\end{array}$ & $\begin{array}{c}15 \\
20.5 \% \\
\end{array}$ & $\begin{array}{c}8 \\
10.9 \% \\
\end{array}$ & $\begin{array}{c}3 \\
4.1 \% \\
\end{array}$ & 2.6 & 1.01 \\
\hline
\end{tabular}

Source: Primary Survey, 2020

3.4.1.1 Existence of Medium-Term Expenditure Framework. Data analyzed in the above table 1.1 showed that the integration issue of planning and budgeting on the MTEFs approach from the total 30 of the respondent is agreed. Therefore, according to the MTEF approach, explained above in detail, the researcher asked whether it is prepared in each spending agency. As a result, most of the respondents, $30(41.1 \%)$ agree and $17(23.3 \%)$, disagree, where $6(8.2 \%)$ strongly disagree with the statement. On the other hand, $12(16.4 \%)$ become strongly agree, 8 (10.9) neutral with the statement. Based on these responses, we can understand that the Woreda government expenditure management system does not fully involve a medium-term perspective, indicating there is no high integration to the medium expenditure framework prepared in each spending. Therefore, in the Yayu Woreda Finance office prioritized the resource to utilized properly is not such much well-integrated accordingly expenditure framework.

3.4.1.2 Linking of the Annual Budget to Physical Plan. For the issue of annual budget linking to physical plan, about $29(39.7 \%)$ respondents agree, and $9(12.3 \%)$ strongly agree and $8(10.9 \%)$ neutral that means there is a mechanism to link the annual budget proposal with the developmental plans of spending agencies. On the other hand, $25(134.2 \%)$ of respondents disagree and 2 (2.7\%) Strongly disagree that there is no mechanism. According to open-ended interview questions, the reason for this is that Yayu woreda Finance Office has already started program budgeting within some budgetary institution. In addition, through the woreda government adopted program budgeting in some spending agencies, its implementation is limited to some sectors office. However, most sectors office of the woreda is still using the line-item budgeting approach. As we know, line-item budgeting is input-oriented and a tool for financial compliance and control. Moreover, evidence from secondary data ensured that there is low utilization of capital budget, which can indicate a lack of integration between plan and budget. As the result of this, there is a gap b/n budget and physical plan linkage, especially at the beginning of the budget year.

3.4.1.3 Relationship between Project Planning and Formulation of Capital Budget. Project planning is concerned with identifying projects that are expected to be undertaken every year, and this plan should be linked with capital budgeting. Accordingly, the researcher asked respondents to rate the relationship between project planning and the formulation of the capital budget. As a result, most of the respondents, 27 (37\%) agree, 9 (12.3) strongly agree and $11(20 \%)$ neutral, and 28 (38.3\%) disagree, which means somewhat there is a medium relationship between project planning linked with capital budgeting. However, 2 (2.74\%) strongly disagree that there is a relationship between the two, but two-point seven percent of the respondents are strongly disagreed; therefore, they lack the planning and formulation capital budget to few extents. In addition, it was revealed from responses to open-ended questions that Yayu Woreda Finance Office does not submit performance plan with the budget proposal; performance plan is submitted by spending agencies themselves to their respective office. It indicates that, the activity of capital budgeting and project planning is not well integrated.

3.4.1.4 Adequate Understanding to Prepare Plan and Budget. Trade-offs and prioritization among programs must be made to ensure that the budget fits government policies and priorities during budget preparation. In addition, the most cost-effective variants must be selected. Finally, the government must have used appropriate measures to increase operational efficiency. None of these can be consummate unless financial constraints are built into the process from the very celebrity. Daily activities for budget administration rest mainly with the spending agencies themselves. Therefore, to achieve sufficient resource allocation, there should be a proper 
analysis of the budget preparation by spending agencies. In the proper analysis of the budget by the spending agencies, most of the respondents are 33 (45\%) agree, 14 (19.18\%) strongly agree and $15(20.56 \%)$ neutral. In other words, from the total respondents, $8(10.9 \%)$ of the respondents disagree, and 3 (4.1) respondents strongly disagree that public agencies analyze their budget in terms of government priority. It was also indicated on the responses for open-ended questions that there are problems in budget preparation. The woreda finance office does not give sufficient time for budget hearings and does not try to check whether spending agencies are requesting a budget for the plan they have. In addition, spending agencies do not have the appropriate standard and unit cost to prepare their budget. It has a negative effect on the preparation thus spending trend.

3.4.2 Mismatching of Budget and Plan. The mismatching of budget and plan is main problem mostly seen in rural woredas of the zone. In the same way this problem also has been seen broadly Yayu woreda Finance office. Therefore, concerning to this the questioner presented for the respondents on reason for this mismatch of the budget and plan were as follow in table 1.2.

Table 1.2 Approving of Budget According Physical Plan

\begin{tabular}{|c|c|c|c|c|c|c|c|c|}
\hline \multirow[t]{2}{*}{ № } & \multirow[t]{2}{*}{ Questions } & \multicolumn{7}{|c|}{ Responses } \\
\hline & & 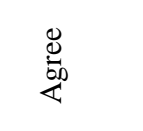 & 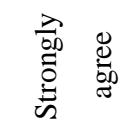 & 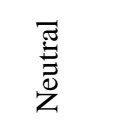 & 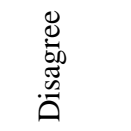 & 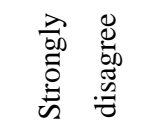 & Mean & $\begin{array}{c}\text { St. } \\
\text { deviation }\end{array}$ \\
\hline 1 & $\begin{array}{l}\text { The woreda administration has } \\
\text { adequate number of professionals? }\end{array}$ & $\begin{array}{c}25 \\
(34.23 \%)\end{array}$ & $\begin{array}{c}5 \\
(6.85 \%)\end{array}$ & $\begin{array}{c}9 \\
(12.3)\end{array}$ & $\begin{array}{c}32 \\
(43.8 \%)\end{array}$ & $\begin{array}{c}2 \\
(2.74 \%)\end{array}$ & 3.14 & 1.21 \\
\hline 2 & $\begin{array}{l}\text { In the woreda administration revising } \\
\text { their plan according to their approved } \\
\text { budget? }\end{array}$ & $\begin{array}{c}25 \\
(34.23 \%)\end{array}$ & $\begin{array}{c}0 \\
(0 \%)\end{array}$ & $\begin{array}{c}2 \\
(2.74 \%))\end{array}$ & $\begin{array}{c}34 \\
(46 \%)\end{array}$ & $\begin{array}{c}12 \\
(16.44 \% 0\end{array}$ & 2.97 & 1.09 \\
\hline 3 & $\begin{array}{l}\text { Other sectors analyze their budget in } \\
\text { terms of their transformation plan? }\end{array}$ & $\begin{array}{c}22 \\
(30,14 \%) \\
\end{array}$ & $\begin{array}{c}0 \\
(0 \%) \\
\end{array}$ & $\begin{array}{c}11 \\
(15.1 \%) \\
\end{array}$ & $\begin{array}{c}31 \\
(42.46 \%) \\
\end{array}$ & $\begin{array}{c}9 \\
(12.3 \%) \\
\end{array}$ & 2.53 & 1.13 \\
\hline 4 & $\begin{array}{c}\text { The offices prepare its annual plan } \\
\text { based on strategies document of the } \\
\text { woreda? }\end{array}$ & $\begin{array}{c}23 \\
(31.51 \%)\end{array}$ & $\begin{array}{c}2 \\
(2.74 \%))\end{array}$ & $\begin{array}{c}8 \\
(10.9 \%)\end{array}$ & $\begin{array}{c}29 \\
(39.7 \%)\end{array}$ & $\begin{array}{c}11 \\
(15.1 \%)\end{array}$ & 2.63 & 1.05 \\
\hline 5 & $\begin{array}{l}\text { Budget is prepared based on reliable } \\
\text { data and reasonable estimated cost? }\end{array}$ & $\begin{array}{c}8 \\
(10.9 \%)\end{array}$ & $\begin{array}{c}2 \\
(2.74 \%))\end{array}$ & $\begin{array}{c}11 \\
(15.1 \%)\end{array}$ & $\begin{array}{c}42 \\
(57.5 \%)\end{array}$ & $\begin{array}{c}10 \\
(13.7 \%)\end{array}$ & 2.67 & 1.15 \\
\hline 6 & $\begin{array}{c}\text { There is a tendency of submitting } \\
\text { budget request without plan? }\end{array}$ & $\begin{array}{c}42 \\
(57.5 \%)\end{array}$ & $\begin{array}{c}5 \\
(6.85 \%)\end{array}$ & $\begin{array}{c}5 \\
(6.85 \%)\end{array}$ & $\begin{array}{c}19 \\
(26 \%)\end{array}$ & $\begin{array}{c}2 \\
(2.74 \%))\end{array}$ & 2.31 & 0.941 \\
\hline
\end{tabular}

Source: Field survey, 2020

3.4.2.1 Knowing Availability of Skilled Manpower to Prepare the Budget \& Plan. According to the respondent's answers, the woreda administration has an adequate number of professionals. $25(34.23 \%)$ of respondents agree, $5(6.85 \%)$ of respondents strongly agree, while $9(12.3)$ of respondents neutral. But most of the respondents, about 32 (43.8\%), disagree and 2 (2.74\%) strongly disagree. Therefore, to some extent, there is a lack of professionals in the woreda that affects the budgetary performance. It was also revealed from the responses for open-ended questions and audit report that the main challenges regarding skilled manpower to planning and budgeting are turnover of the employee, lack of training, the low commitment of leadership, too ambition, lack of momentum in the short term \& lack of rewards for best performance, etc. Therefore, in the woreda there is a variation of the budget with a plan. The main causes of the interpretation according to open-ended interviews, in the woreda they do not take corrective action as the auditors recommend and suggest, budgets are too rigid and prevent fast response, lack spending budget according to the priorities \& monitoring and evaluation is not performed constantly etc.

3.4.2.2 Revising Their Plan According to Their Approved Budget. According to the respondents' responses, shown above in table 1.2, $25(34.23 \%)$ agree, $2(2.74 \%)$ neutral while $34(46 \%)$ disagree, and $12(16.44 \%)$ strongly disagree. Consequently, the mismatching of the plan and budget has been seen in the Woreda. In the same way for the closed and opened question raised about variation of plan with most of the respondents about $59(80.82 \%)$ were given their response on 'Yes' that is there is a variation of plan with budget, $12(16.44 \%)$ respondents were given their response on 'No' that is there is no variation of plan with budget and $2(2.74 \%)$ respondents have no comment.

3.4.2.3 Analyze Their Budget in terms of Their Transformation Plan. According to the responses concerning the budget analysis in terms of transformation plan as in table 4.2, about $31(42.46 \%)$ disagree and $9(12.3 \%)$ strongly disagree. In the woreda, there is a variation of appropriation and spending, in the open-ended interviews and according to the report revealed by the Planning and Budget Department of Yayu woreda 
finance office in 2012 E.C (Ethiopian Calendar) annual report, the following problems were observed by budget users in coordination with the plan and budget preparation. For instance, the following problem also addressing:

$>$ The plan and budget were prepared without fully participating, discussing, and approving concerned units and persons. As a result, presenting the exaggerated budget, overlooking programs, and an excess budget transfer and adjustments happened.

$>$ The prepared budget did not include the relevant issues and the office's strategic plan fully.

$>$ Presentation of budget demand without work plan for some extents.

$>$ Lack of Reasonable and proper predictable inflation.

$>$ Lack of revising budget with plan constantly etc. in such sectors offices there is a variation of budget and plan at the woreda administration of finance office. A problem of budget analyzing in terms of transformation plan which affect the budget performance of the woreda while $22(30.14 \%)$ of the respondents agree and 11 $(15.1 \%)$ respondents' responses were neutral this indicated that rarely there is budget analyzing in terms of the transformation plan.

3.4.2.4 Prepare Annual Plan Based on Strategies Document. In relation to this question, the response given by respondents as illustrated in above table 4.2 out of the total respondents about 22 (330.14) respondents agree, $2(2.74 \%)$ strongly agree while $8(10.9 \%)$ of the respondents gave a neutral response. On the other hand, most of the respondents, $29(39.7 \%)$, disagree, and $11(15.1 \%)$ respondents strongly disagree with the question. Therefore, the researcher can conclude that there is no adequately prepared annual plan based on a strategic document in the finance office of the woreda.

3.4.2.5 Budget is Prepared Based on Reliable Data and Reasonable Estimated Cost. Based on the response of respondents listed on table 4.2 about budget prepared based on reliable data and reasonable estimated cost, the number of respondents agrees the idea was $8(10.9 \%)$, those strongly agree $2(2.74 \%)$ and those have neutral idea were $11(15.1 \%)$ while the number of respondents disagree and strongly disagree $42(57.5 \%)$ and $10(13.7 \%)$ respectively. From this information, the researcher was understood as budget is not prepared based on reliable data and reasonable estimated cost in the woreda finance office.

3.4.2.6 There is a Tendency of Submitting Budget Request Without Plan. The information obtained from the respondents listed in table 1.2 , memorizing that about $42(57.5 \%)$ of the respondent agree, $5(6.85 \%)$ of the respondents strongly disagree and $5(6.85 \%)$ of the respondents support neutral, that there is a tendency of submitting a budget request without a plan. Accordingly, about $19(26 \%)$ of the respondents disagreed with the idea, whereas $2(2.74 \%)$ strongly disagree; that is, no.

\subsection{The Importance of Knowing Budgetary Performance}

3.5.1 Budget Expenditure of the Woreda Administration. The budget nature differs from nation to nation because of the specific country's economic, social, and administrative realities and trends. Therefore, multiple factors to consider to analyzing budget and expenditure, Comparison between appropriations and actual spending of recurrent and capital budget, the proportion of money and recurrent funding, and Growth and Transformation Plan (GTP) budget and actual budgeting comparison are presented consecutively to achieve the objective and to identified the variation of budget and plan for low budget utilization performance.

3.5.1.1 Comparison of Budget Versus Expenditure. The comparison of budget and expenditure for both types (recurrent and capital) was for presenting and analyzing the consecutive improvement for the woreda budget utilization performance according to the woreda monitoring and evaluation criteria.

3.5.1.1.1 Recurrent Budget. A recurrent budget tracks ongoing revenues and expenses regularly, whether monthly, quarterly, semiannually or annually. Also known as an operational budget, a recurrent budget includes line items such as wages, utilities, rent or lease payments, and taxes. Recurrent budget is used for daily operational activities that do not have a long-term nature and exhausted within the fiscal year. 
Table 1.3 Comparison of Appropriation and Actual Spending for Recurrent for Recurrent by Budget Years

\begin{tabular}{|c|c|c|c|c|}
\hline Fiscal Year & Total appropriations & Total actual spending & Difference & $\begin{array}{c}\text { Percentage of spending from } \\
\text { the appropriations }\end{array}$ \\
\hline 2006 & $31,064,711.8$ & $31,063,511.2$ & 1200.15 & $99.9 \%$ \\
\hline 2007 & $47,247,171.3$ & $51,47159,571$ & 87600.32 & $99.8 \%$ \\
\hline 2008 & $59,343,360.3$ & $59,143,295.3$ & 200,065 & $99.6 \%$ \\
\hline 2009 & $62,704,264$ & $62,704,264$ & 0 & $100 \%$ \\
\hline 2010 & $82,961,087.4$ & $82,937,987$ & 23,100 & $99.9 \%$ \\
\hline 2011 & 90832142 & $90,802,110.6$ & $30,031.41$ & 99.9 \\
\hline
\end{tabular}

Source: Yayu finance office 2006-2012 final yearly report

Table 1.3 shows the total appropriations for recurrent budget for the woreda government and the actual yearly spending from its appropriations. Consequently, the total appropriation for this budget type increases from year to year because of the increment in the total national budget, especially since woreda administration has responsibility for design, management, and follow-up of the implementation of various reforms. On the other hand, regarding the total actual spending from its respective appropriation, the spending increases across the years. According to the interview result, the reason for this is that there is an increment in the prices of goods and services, new housing development projects, the salary increment made nationwide and new employees are joined the woreda as a result of new organizational structure allowed recently budget year and improvements employee performance. There is $0-0.04 \%$ of difference. Therefore, there is no significant difference in absolute amount between the appropriation and the actual spending of the Woreda administration; the percentage of expenditures shows a somewhat uniform pattern. However, as an open-ended question and the annual report show, there is idle budget display at the end of the budget year, there is a low linkage of plan and budget as discussed above. For example, the year 2006 is less than the approved budget of the particular year. The difference is birr 121,212.15 which is about $0.35 \%$ of the total budget approved for the respective year. Similarly, the total spending made during 2012 is birr 2,534,657.15 less than the appropriation, accounting for about $2.25 \%$ of the approved budget. Therefore, this truth can be justified as the percentage change in utilization is small because both budget and expenditure indicate a similar pattern. However, the Woreda administration of the budget increased year after year so that as shown in table 1.3, appropriation of recurrent budget against spending is incrementing trend. Therefore, there is an increase of a difference, so the woreda has a variation of the budget with a plan according to setting priority strategies but not the fact that show there is a difference of budget performance.

3.5.1.1.2 Capital Budget. Capital budgeting is the planning process that is used to determine whether an organization's long-term investments such as new machinery, replacement of machinery, new plants, new products, and research development projects are worth the funding of cash through the firm's capitalization structure. Capital budgeting makes decisions about the long-term investment of a woreda capital into operations. Planning the eventual returns on investments for different are all examples of capital budgeting. The tables 4.4 given below showed that the total appropriations of the capital budget for the woreda government and the actual yearly spending. As a result, the total appropriations for this budget type increases from year to year. According to the respondents for interview questions, the main reason for this continuous increment is due to the Government to give attention for developmental activities and increasing Tax revenue consists of the income received from different taxes and other duties levied by the government in Growth and Transformation Plan by lunched huge project such as basic infrastructures for specific operation to fulfill the demands of the public in the Woreda.

Table 1.4 Comparison of Appropriations and Actual Spending for Capital Budget

\begin{tabular}{|c|c|c|c|c|}
\hline Fiscal Year & Total appropriations & Total actual spending & Difference & $\begin{array}{c}\text { Percentage of spending } \\
\text { from the appropriations }\end{array}$ \\
\hline 2006 & $3,451,634.60$ & $3,331,622.6$ & 120,012 & $96.5 \%$ \\
\hline 2007 & $5,249,685.7$ & $4,149,609$ & $1,100,076$, & $79.04 \%$ \\
\hline 2008 & $6,5937,06.7$ & $6,193,205.98$ & $400,500.72$ & $93.9 \%$ \\
\hline 2009 & $6,967,140.5$ & $6,967,140.5$ & 0 & $400 \%$ \\
\hline 2010 & $9,217,898.6$ & $4,217,825.6$ & $5,000,073$ & $78.75 \%$ \\
\hline 2011 & $10,092,460$ & $7,883,460$ & $2,209,000$ & $77.8 \%$ \\
\hline 2012 & $11,269,447$ & $8,769,396.85$ & $2,500,050$ & \\
\hline
\end{tabular}

Source: Yayu woreda Finance Office (2006-2012) final yearly report 
4.5.1.1.3. Proportional of Capital and Recurrent Budget. Differentiating the proportion of each budget type is very important to evaluate whether the woreda administration gives due emphasis to developmental or nondevelopmental activities.

Table 1.5 Comparison of the Proportion of Capital and Recurrent Budget

\begin{tabular}{|c|c|c|c|c|c|}
\hline \multirow{2}{*}{$\begin{array}{c}\text { Fiscal } \\
\text { year }\end{array}$} & Total budget & \multicolumn{2}{|c|}{ Recurrent budget } & \multicolumn{2}{c|}{ Capital budget } \\
\hline 2006 & & Amount & Percentage & Amount & Percentage \\
\hline 2007 & $34,516,346$ & $31,064,711.8$ & $90 \%$ & $3,451,634.60$ & $10 \%$ \\
\hline 2008 & $52,496,857$ & $47,247,171.3$ & $90 \%$ & $5,249,685.7$ & $10 \%$ \\
\hline 2009 & $65,937,067$ & $59,343,360.3$ & $90 \%$ & $6,593.706 .7$ & $10 \%$ \\
\hline 2010 & $69,671,405$ & $62,704,264$ & $89.9 \%$ & $6,967,140.5$ & $10 \%$ \\
\hline 2011 & $92,178,986$ & $82,961,087.4$ & $90 \%$ & $9,217,898.6$ & $10 \%$ \\
\hline 2012 & $100,924,602$ & $90,832,142$ & $90 \%$ & $10,092,460$ & $9.9 \%$ \\
\hline
\end{tabular}

Source: Yayu woreda Finance Office 2006-2012 final yearly report

As the idea on table 1.4 above illustrated that the proportion of the capital and recurrent budget shows a general increasing trend for recurrent and capital respectively in each year. Hence, the recurrent budget has been a proportion of $90 \%$ from 2006 year to 2012 Ethiopian budget year. Capital budget on the other hand, indicated the same manner $10 \%$ constant from 2006-2012 but it is decrease $9.9 \%$ in 2011 budget years. However, the woreda more focused for infrastructure, job creation to job lack of the youth and developmental activities, the fact and the woreda annually report indicate but there is a problem on project implementation and controlling. Generally, the above table showed that, the woreda administration more focus for developmental infrastructure in the form 2006-2012 Ethiopian budget however, there is more idle budget in the capital budget rather than recurrent budget and recently the annual report of the Yayu Woreda Finance office of 2012 E.C also showed that, there is lack of capital budget utilization and controlling due to weak project managements.

4.6 Implementation and Controlling Issues of Public Spending. The selected woreda has budgetary or appropriation accounting that consists of tracking and registering operations concerning appropriations and their uses. It also covers appropriations, allotment, any increase or decrease in appropriations, commitments/obligations, expenditures at the verification/delivery stage, and payments, budgetary accounting is only one element of the government accounting system, but it is the most vital for both formulating policy and supervising budget implementation. Budgetary accounting and recording weaknesses make a quality analysis of the performance, outputs, or outcomes impossible. Most developed countries keep registers for their transactions at each stage of the expenditure cycle or at least at the obligation and payment stages. This, whatever their accounting system or budget execution procedures. Many developing countries keep similar registers, either at the spending agency level or through centralized control procedures. Though, in both cases, budgetary accounting presents inadequacies.

On the one hand, when agencies keep registers, information is not systematically available at the level of the Ministry of Finance, which would need it to supervise budget implementation. In fact, in some of these countries, budgetary accounting covers only payments. However, where control procedures are centralized, sometimes information on budget execution concerns administrative steps that do not correspond to the stages in the expenditure cycle. Such "administrative" information is useless for analyzing budget implementation. In spending agencies keep books on an "accumulation" basis such arrangements, regardless of their advantages, created difficulties in the timely monitoring payments according to the budget categorization. Therefore, in these spending agencies, efforts are currently focused on implementing a system of monitoring payments. The benefits of monitoring either obligations or expenditures at the verification stage or the payments stage are sometimes debated. Information is needed at each stage of the expenditure cycle and can be easily compiled, thanks to developments in electronic technology. Adequate recording of appropriations, revisions in appropriations, transfers between appropriations, actual spending, etc., is a prerequisite for good management. It is difficult to know which budget is implemented in several developing countries because decisions concerning allocations and reallocations of appropriations are contained in various circulars and are not gathered into a single document. The budget implementation plan should be updated regularly to consider decisions concerning appropriations. 
Table 1.6 Budget Utilization and Control

\begin{tabular}{|c|c|c|c|c|c|c|c|}
\hline \multirow[t]{2}{*}{ № } & \multirow[t]{2}{*}{ Question } & \multicolumn{6}{|c|}{ Response } \\
\hline & & Yes & $\%$ & No & $\%$ & $\begin{array}{c}\text { No } \\
\text { comment }\end{array}$ & $\%$ \\
\hline 1 & $\begin{array}{l}\text { Do budgetary institutions use their } \\
\text { budgets based on their planned cash flows? }\end{array}$ & 13 & 17.8 & 51 & 69.86 & 9 & 12.3 \\
\hline 2 & Do sectors frequently ask budget transfers? & 52 & 71.23 & 18 & 24.65 & 3 & 4.1 \\
\hline 3 & $\begin{array}{l}\text { Do you have a budgetary control system } \\
\text { which enables the budgetary institutions to } \\
\text { report on their budgeted and actual } \\
\text { expenditure? }\end{array}$ & 30 & 41.1 & 39 & 53.42 & 4 & 5.5 \\
\hline 4 & $\begin{array}{l}\text { Does your bureau prepare } \\
\text { explanatory and complete } \\
\text { implementation reports to } \\
\text { administration council? }\end{array}$ & 30 & 41.1 & 37 & 50.7 & 6 & 8.2 \\
\hline 5 & $\begin{array}{l}\text { Do budgetary institutions keep complete } \\
\text { and reliable budgetary records? }\end{array}$ & 24 & 32.8 & 36 & 49.3 & 13 & 17.8 \\
\hline
\end{tabular}

Source: Field survey 2012 (2020 G.C)

4.6.1 Budget Utilization Based on Cash Flow. During the implementation stage, spending agencies must prepare the cash budget and act accordingly. Regarding budget utilization based on cash flow, most respondents $51(69,86 \%)$ ensured that budgetary institutions do not use their budgets based on their planned cash flow or cash budget. However, $13(17.8 \%)$ respond that sectors use their budget based on cash flow, and $9(12.3 \%)$ respond to no comment. Although evidence from financial office reports showed that most of the budget is spent on the increased and decrease pattern, variation has been seen each budget year. Moreover, responses from the open-ended question and interviewed indicate that there is a practice among most sectors to use their budget on timely based on their cash budget except some sectors under the Finance Office in the woreda. These all can result in the budget to be under spending, hence affects the spending trend. However, the main advantages of budget utilization are based on cash flow that helps determine whether cash balances remain sufficient to fulfill regular obligations and whether banks set minimum liquidity and cash balance requirements. It also helps determine whether too much cash is retained that could be nothing rather than using for effective activities. Budget utilization based on cash is a basic issue for the woreda administration of the finance office. As the interview, they control the budget by a system of integrated budget and expenditure system (IBEX).

4.6.2 Budget Transfers. When acting, the beneficiary may adjust the estimated budget by budget transfers between eligible costs, but once the budget is proclaimed, expenditure is supposed not to exceed the approved budget. However, whatsoever properly formulated budget exists, the future may not be as expected. The budget transfer should not be the main function of budgetary institutions. However, under certain circumstances and urgent situations, public bodies are permitted to perform the transfers. But, if transfers are frequent, it may be due to inadequate preparation of the budget. The researcher analysis in table 4.6 above $52(71.23 \%)$ and 18 (24.65\% respond yes and no for frequent transfer requests. Therefore, there is a budget transfer special at the end of the budget year because of less commitment on planning, budget preparation, over and underutilization of budget, lack of revising of the budget according to approved budget and rarely submitting of the budget without plan also a critical problem on budget utilization, however, on the open-ended interviews there is a way of transfer budget request permitted by law, but some sub-cities have been more requested rather than the law allowed special at the end of the budget year.

4.6.3 Budget Control System. A budgetary control system is a system which uses budgets to control spending. According to budget administrative manual of the Woreda the basic feature of this system includes:

Planning the activities to achieve the objectives including the preparation of budgets.

Recording the actual expenditure incurred,

$>$ Comparing actual costs (results) against the plan (budget),

$>$ Investigating material variables,

Taking corrective actions

Reviewing and revising plans in the light of circumstances or changes that have been taken place, most of the respondents $39(53.43 \%)$ do not ensured that the system is existing. However, interview with the Finance and current audit center process proprietor ensured that, even though the system is established, there are challenges in adherence to it.

4.6.4 Submission of Reports on Their Budgeted and Actual Expenditure. The analysis showed 30 (41.1\%) of the respondents said yes, $37(50.7 \%)$ of respondents said no, and $6(8.22 \%)$ of the respondent said no 
comment. Therefore, there is dalliance in the submission of budget utilization reports on a timely basis. However, in the open-ended interview, the respondents were supporting the issue. In addition to the Finance and Modern audit core process owner ensured that the focus of the report is only on the financial aspect and does not include the physical performance of projects. Because the reporting system is focused on financial performance rather than physical performance and there is a delay of the report to submit the concerned body and there is no corrective action taken immediately by the top management, the fact also supports. The experts address the problem and show reports.

4.6.5 Availability of Complete Budgetary Records. To compare actual spending with the approved budget and to take corrective action if actual spending deviates from budgeted. The analysis show, 29 (54\%) respond no. On the other hand, $25(46 \%)$ respondents ensured that there are budgetary institutions maintain proper budgetary records. On the contrary, evidence from the audit reports of finance office and current audit of the woreda finance office ensured that there are budgetary institutions which do not maintain complete budgetary records. Instead of this there is a problem of completed recording of a budgetary data due to the following factors:

$>$ Poor budget preparation;

$>$ Lack of necessary and completed document;

$>$ Requesting payment without approved budget;

$>$ Trends of high request budget transfer at the end of budget year.

4.7 Methods Used to Follow and Prepare Good Budget. To prepare good budget and following its performance the following way of auditing and control is very important in the finance office. Therefore, the researcher prepares some closed and opened questions presented for the respondents according to the following.

4.7.1 Performances of Auditing and Internal Controls for Allocated Budget. Performance auditing is a systematic, objective assessment of the accomplishments or processes of a government program or activity to determine its effectiveness, economy, or efficiency. This determination, along with recommendations for improvement, is reported to managers, ministers, and legislators responsible for enacting the recommendations or ensuring accountability for corrective action. Performance auditing is an important building block with which to improve accountable and responsive governance of public resources. As government programs continue to grow in magnitude and complexity, public sector auditing has evolved and extended its scope beyond mere financial or compliance audits to auditing performance to support policymakers in their oversight role. Performance of auditing is a very new development in the history of auditing. Its growth parallels the evolution of politics and public administration from a one-dimensional focus on control of inputs (resources) toward broader attention to accountability for outputs and outcomes. This evolution of auditing represents both a means by which auditors can continue to be relevant and a move toward fulfilling their accountability role in governance.

Table 1.7 Performing of Auditing for Allocated Budget

\begin{tabular}{|c|c|c|c|c|c|c|c|c|}
\hline \multirow[b]{2}{*}{ № } & \multirow[t]{2}{*}{ Questions } & \multicolumn{7}{|c|}{ Responses of respondents } \\
\hline & & Agree & $\begin{array}{l}\text { Strongly } \\
\text { agree }\end{array}$ & Neutral & Disagree & $\begin{array}{l}\text { Strongly } \\
\text { disagree }\end{array}$ & Mean & $\begin{array}{c}\text { St. } \\
\text { deviation }\end{array}$ \\
\hline 1 & $\begin{array}{l}\text { The bureau has adequate internal } \\
\text { audit controls system to ensure } \\
\text { that funds are utilized for the } \\
\text { intended purpose. }\end{array}$ & $\begin{array}{c}23 \\
(31.5 \%)\end{array}$ & $\begin{array}{c}2 \\
(2.74 \%)\end{array}$ & $\begin{array}{c}13 \\
(17.8 \%)\end{array}$ & $\begin{array}{c}27 \\
(36.9 \%)\end{array}$ & $\begin{array}{c}8 \\
10.9 \%\end{array}$ & 3.64 & 1.05 \\
\hline 2 & $\begin{array}{l}\text { All budgetary of the sectors of the } \\
\text { woreda have adequate internal } \\
\text { control audit section/unit? }\end{array}$ & $\begin{array}{c}15 \\
(20.5 \%)\end{array}$ & $\begin{array}{c}2 \\
(2.74 \%)\end{array}$ & $\begin{array}{c}3 \\
(4.1 \%)\end{array}$ & $\begin{array}{c}40 \\
(54.8 \%)\end{array}$ & $\begin{array}{c}13 \\
(17.8 \%)\end{array}$ & 3.34 & 1.24 \\
\hline 3 & $\begin{array}{l}\text { Internal auditors of budgetary } \\
\text { institutions independently conduct } \\
\text { their duties and responsibilities? }\end{array}$ & $\begin{array}{c}15 \\
(20.5 \%)\end{array}$ & $\begin{array}{c}13 \\
(17.8 \%)\end{array}$ & $\begin{array}{c}7 \\
(9.58 \%)\end{array}$ & $\begin{array}{c}32 \\
(43.83)\end{array}$ & $\begin{array}{c}6 \\
(8.3)\end{array}$ & 3.25 & 1.14 \\
\hline 4 & $\begin{array}{l}\text { Yayu finance have enforcing } \\
\text { mechanism to implement } \\
\text { (improve) the audit comments of } \\
\text { the Auditor General of the Ilu Aba } \\
\text { bor Zone? }\end{array}$ & $\begin{array}{c}7 \\
(23.3 \%)\end{array}$ & $\begin{array}{c}2 \\
(2.74 \%)\end{array}$ & $\begin{array}{c}7 \\
(9.58 \%)\end{array}$ & $\begin{array}{c}42 \\
(57.5 \%)\end{array}$ & $\begin{array}{c}5 \\
(6.8 \%)\end{array}$ & 3.23 & 1.10 \\
\hline 5 & $\begin{array}{l}\text { Internal auditors conduct } \\
\text { performance auditing to evaluate } \\
\text { efficiency and effectiveness of } \\
\text { budget utilization? }\end{array}$ & $\begin{array}{c}26 \\
(35.6 \%)\end{array}$ & $\begin{array}{c}9 \\
(12.3 \%)\end{array}$ & $\begin{array}{c}9 \\
(12.3 \%)\end{array}$ & $\begin{array}{c}24 \\
(32.87 \%)\end{array}$ & $\begin{array}{c}5 \\
(6.8 \%)\end{array}$ & 3.64 & 1.04 \\
\hline
\end{tabular}

Source: Field survey, 2012 (2020) 
4.7.1.1 Adequacy of Internal Control. Generally, controls can be evaluated and improved to make the Woreda administration of finance office performance sprint more economically, effectively to use the limited resources. So, internal control is the methods and procedures within the sectors of the Woreda established to safeguard assets, check the accuracy and reliability of financial and other data, promote operational efficiency and encourage adherence to the prescribed policies and procedures of the finance office. Moreover, it can also help to ensure reliable financial reporting and compliance with laws and regulations. Based on this idea, the researcher was asked to rate the respondents whether there is an adequate internal control or not. According to the response of the respondents, $23(31.5 \%), 2(2.74 \%)$, and $13(17.8 \%)$ become agree, strongly and neutral respectively to the issue. However, most of the respondents 27 (36.9\%) disagree and 8 (10.9\%), strongly disagree on the issue; this indicated that there is no well-organized internal control. On the other hand, evidence gathered from plan, budget, monitoring and evaluation sub-process owner in the office did not have a stable human resource skills workforce. The requirement of the position or job specification in the BPR study did not meet relevant criteria with the position of the requirements. It indicates that there is no well-functioning adequate internal control system, hence affects the spending trend by either reducing or increasing the expenditure other than real amount.

4.7.1.2 Internal Audit Section in Each Budgetary Sectors. An internal audit section helps any offices conduct a thorough examination of the accounting process, including the whole system, and allows whether transactions are recoded properly, and the system is operated efficiently. Accordingly, a question about the existence of an internal audit section in all budgetary sectors is asked. Consequently, most respondents -29 $(54 \%)$ and $14(26 \%)$ agree and neutral, respectively, on the issue. On the other hand, $7(13 \%)$ and $4(7 \%)$ disagree and strongly disagree on the issue. It indicates that its existence can be contributing a lot towards the good management of public expenditure if it operates as per the principles of auditing and has a positive impact on the spending trend, but they are not well structured and organized.

4.7.1.3 Independence of the Internal Auditors. An internal audit "can be critical to the successful operation and growth of any Bureau before the external audit team even begins to add their value. According to the woreda finance office, internal auditing is an independent, objective assurance and consulting activity designed to add value and improve an organization's operations. It helps offices of each sector to accomplish its objectives by bringing a systematic, disciplined approach to evaluate and improve the effectiveness of risk management, control, and governance processes." The mere existence of an internal audit section in budgetary offices becomes worthless unless its auditors perform their duties and responsibilities independently. Based on this essence of auditing, respondents were asked to rate the independence of internal auditors. Consequently, most respondents, 32 (43.83) and 6 (8.3\%), disagree and strongly disagree, respectively. On the other hand, 15 (20.5\%) agree, $13(17.8 \%)$ strongly agree, and 7 (9.58\%) become neutral on the matter. It indicates that the independence of internal auditors in the Woreda is not as per principles. Therefore, if auditors lack independence, they cannot perform their duties properly. Lack of good audit will lead to failure in implementing the budget properly. This, in turn, may increase expenditures or underutilize the budget, misusing of budget \& increased transfer of budget in such situation in the offices there is not good independence of internal auditors there for the transaction of an office affects the spending trend. Besides their independence, auditors should possess the required professional skill to perform their duties accurately. Consequently, a question concerning the professional skill of the internal auditors was asked to respondents, as showed in table 1.7. It indicates that internal auditors in the woreda do not possess the necessary skill and knowledge to perform their duties appropriately. This in turn, may increase the expenditure of the woreda than the approved budget.

4.7.1.4 Timely Improvement the Recommendations of the Auditor General. Generally, budgeting is a cyclical decision-making process for allocating limited financial resources to achieve organizational priorities and objectives over a specific period. Therefore, they need to improve the audit comment on a timely basis by using systematic mechanize to follow the budget implementation according to the approved budget or not in such a situation in the woreda administration. Accurate and timely implementation of the recommendation of the external auditors' report eliminates waste, corrects inefficiencies, and improves office performance. Accordingly, there is a question whether Yayu Woreda Finance office has a mechanism to enhance comments forwarded by the Auditor General of the woreda has been asked to respondents. So, 17 (23.3\%), 2 (2.74\%) and $7(9.58 \%)$ agree and strongly agree, neutral on the issue, respectively. However, some respondents, $42(57.5 \%)$, disagree, and 5(6.8\%) strongly disagree on the issue. In addition, evidence from Modern internal audit core process owner, the woreda government, has started from integrated budget and expenditure system (IBEX) had a simple mechanism to implement as comments of the Auditor General of the woreda administration, in some extents, there is lack of improvement as they recommend. 
4.7.1.5 Conducting Performance of Audit by Internal Auditors. Performance auditing is an independent auditing process aimed at evaluating the measures instituted by management or the lack of these measures to ensure that resources have been acquired economically and utilized effectively. In addition, performance auditing is the responsibility of both internal and external auditors. Therefore, respondents were asked whether the inspection section of budgetary sector offices conducts performance auditing or not. Accordingly, most of the respondents, $26(35.6 \%), 9(1203 \%)$ and 9 (1203\%), agree, neutral and strongly agree on the issue, respectively. On the other hand, $24(32.87 \%)$ disagree, and $5(6.8 \%)$ strongly disagree on the issue. It indicated that there is somewhat no weakness in the issue. However, if auditors fail to evaluate the effectiveness of public spending, implementers become careless in giving attention toward achieving the efficiency and effectiveness in public spending. This fact again can lead toward rush year-end spending and budget to the left used that affects technical efficiency and failure to implement the projects that affect outcome thus the effectiveness.

\section{Conclusion and Recommendation}

4.1. General Overview. It includes the findings and recommendations based on the idea stated in the objectives and research questions. The study focused on the assessment of the budgetary performance in the case of Yayu Woreda finance office (YWFO). For this reason, it reviewed pertinent literature and documents and collected data from the targeted population. Therefore, during the analysis, the following findings were identified basically, as the study focuses on the budgetary performance in the case of Yayu Woreda finance office. It also identifies the challenges that hinder the plan and budget integration, the importance of budgetary performance (budget and expenditure), implementation and methods of budgetary performance (controlling \& auditing performance) in the woreda administrational budget based on evidence from the Yayu Woreda finance office. To achieve the study's objectives, the researcher employed a mixed research approach and used both primary and secondary data sources. It ensures the sufficiency of data and triangulation purpose so that the reliability and validity of the research findings become enhanced. Therefore, based on the finding of the study, conclusions are forwarded as follows.

4.2 Conclusion. The current study ensured that small-scale business leadership factors are of much concern to the Finance Office's budgetary performance in the woreda. For instance, all budgetary offices of the Woreda government expenditure management system do not fully involve a medium-term perspective, indicating there is no high integration to the medium expenditure framework prepared in each spending. It means that each sector office uses their budget from the finance office without integrating plan and budget. Even if their activities are based on their plan, the planning and budget department does not arrange regular workshops and short-term training to improve the skill of budget personnel engaged in budget holders and the adequate understanding of budget preparation. The expenditure management system of woreda government does not fully involve a medium-term perspective, indicating there is no integration to the medium expenditure framework prepared in each spending. Therefore, in the Yayu Woreda Finance Office, prioritizing the resource to utilize properly is not well integrated accordingly expenditure framework. The main challenges regarding skilled manpower to planning and budgeting are turnover of the employee, lack of training, the low commitment of leadership, too ambitious, lack of momentum in the short term \& lack of rewards for best performance etc.

Hence, the budget and plan department takes the lion's share of responsibility for budget integration problems. So that it is difficult to link the budget with the performance goals and objectives of budgetary office in the Yayu Woreda Finance Office. On the other hand, the study ensured that the budget expenditure in both budget types, the appropriation budget increase in each year the proportion recurrent to capital indicated increasing trend all over the study periods. This kind of budget increment in each year was due to the woreda administration more focus on developmental infrastructure in the form 2006-2012 Ethiopian budget. However, there is more idle budget in the capital budget than recurrent budget as recently the annual report of the werda shows. Additionally, there was a tendency to submit a budget without a plan. Though such activities were improved from time to time in the recurrent budget but not in the capital budget, the variance increases relatively to a recurrent budget. So, there is an idle budget in the cause of a comprehensive, coordinated and adequate budgetary reporting system is not a prerequisite for good budgetary performance. In addition to this, there is other high budget transfer requesting and there is no implement a control system properly. That is why some budgetary sectors fail to submit their reports timely and lack complete recording. That means there is dalliance of the submission of budget utilization report on a timely basis. Therefore, Yayu Woreda Finance Office fails to take corrective action when actual results deviate from the plan. Moreover, the reporting system was fragmented in that Yayu Woreda finance office that submitted to the administrational council. As a result, only the financial performance and physical performance of projects are submitted by the budgetary sectors themselves. It failed to correct the problem timely and the budget to be left unused. As the current study 
indicated, there was no somewhat weakness about a control system in the office. Still, there were deficiencies in the internal control system implementation practically in the independence and professional skill of internal auditors that was doubtful because the independence of internal auditors in the Woreda becomes not as per principles. Besides, some internal auditors do not perform their auditing performance properly. As they recommend, there is a lack of improvement, which adversely affects the efficiency and effectiveness of public spending. Therefore, there was the fund lack of properly utilizing for the intended purpose.

4.3. Recommendation. According to the general objective, this thesis paper's main intention is to identify the fundamental causes of Yayu Woreda Finance office. Budget implementation and control (performance) weaknesses observed in budget users. Therefore, suggesting possible recommendations to overcome such problems is very important. So, the following recommendations were suggested:

The expenditure management of the Yayu Woreda Finance Office is supposed to have medium-term framework by encouraging budgetary institutions to prepare and implement properly.

$>$ The preparation of the budget should be based on adequate controls and professionally skilled manpower.

$>$ The budget is prepared based on estimated and reasonable costs and should be revised according to their plan.

$>$ Budget implementation involves a significant number of players than budget preparation. Thus, decisionmaking should be given to lower-level units to build responsiveness and accountability on the efficient utilization of their budgets.

$>$ The opinions suggested by the Office of Zonal Auditor General should be considered thoroughly.

$>$ The woreda's finance office enables modifying the budgeting system to improve management decisions and facilitate the attainment of the firm's objectives. The management, on its part, should widen the areas of decision-making by using a reliable, good budget system.

$>$ The finance organization uses appropriate allocation of budget to performing the financial activities of the organization.

$>$ Use an active coordination system: which helps the Finance office, from the top managers to the low-level managers, coordinate and communicate properly.

$>$ Active participation of all employees in their specific job is essential for the woreda's Finance Office to minimize budget problems.

$>$ Responsibility and assignment of authority are essential for preparing good budgeting. The office should give employees authority and duties to prepare good budget system.

$>$ For providing a better reporting of budget performance, use or increase the professional organization employees.

Finally, the office should be taken all possible and remedial actions to remedy the observed weaknesses and avoid repetition of the problems in subsequent years. As a result, the vision of the sectors to build competent employees with efficient cost utilization will be certainly achieved provided that its budgetary performance is fully internalized among budget integration with the plan, taking corrective action, properly utilization of budget and auditing performance and internal control in the woreda administration of finance office.

Funding. There is no funding for this research.

\section{Abbreviation \& Acronyms}

BPR: Business Process Reengineering

CSA: Central Statistics Agency

EMA: Ethiopian Metrological Agency

GTP: Growth and Transformation Plan

IBEX: Integrated budget and Expenditure System

SPSS: Statically Package for Social Science

VFM: Value for Money

YWFO: Yayu Woreda Finance Office

\section{References}

1. Afemikhe, S.O. (2003). The Pursuit of Value for Money. Ibadan: Nigeria Spectrum Books Limited, 75-162. [CrossRef] 
2. Alemayehu G., Dawit B. (2011). Spending without proper planning: A Macro Perspective. IAES Working Paper Serious NO A10/2011. Available at: [Link]

3. Anderson, E. (2011). The Gravity Model. Annual Review of Economics, 3, 133-60. [CrossRef]

4. Anand, M., Sahay, B.S., \& Saha, S. (2004). Cost Management Practices in India: An Empirical Study. ASC1 Journal of management, 33(1-2), 1-13. [Google Scholar]

5. Arora, M.N. (2003). Cost accounting principle and practice, New Delhiviskas, $8^{\text {th }}$ Ed. [Google Scholar]

6. Bartle, J. (2001). Evolving Theories of Public Budgeting. JAI press. [Google Scholar]

7. Bartle, J. (2008). Applying Pragmatism to Public Budgeting and Financial Management. Texas State University. [Google Scholar]

8. CIMA \& ICAEW (2004). A report on Better Budgeting Forum. July, 2004. Available at: [Link]

9. Edinah M., Isaboke J. (2016). Assessment of budgeting process on financial performance of county government. International Journal of Economics, Commerce and Management United Kingdom, IV(5), 134-150. Available at: [Link]

10.Esayas, A., Befkadu, M., Mangistu, G. (2014). Assessment of budget implementation and control in case of Kolfe Keranyo Sub-city. St. Mary's University, Addis Ababa. Available at: [Link]

11.Guilding, C., Cravens, K.S., \& Tayles, M. (2000). An international comparison of strategic management accounting practices. Management Accounting Research, 11(1), 113-135. [Google Scholar] [CrossRef]

12.Hailemeskel, E. (2018). Assessment on budget implementation and controlling: Case of Addis Ababa city Adminstration finance and economic Development bureau. Addis Ababa. Available at: [Link]

13.Henry, N. (1975). Paradigms of public administration. Public Administration Review, 35, 378-386. [Google Scholar] [CrossRef]

14.Hildereth, K. (2002). Budget Theory in Public Sector. Qourum Books, 297 p. [Google Scholar]

15.Hilton, R.W., Maher, W.M., Selto, F. (2000). Cost management strategies for Business Decisions. McGraw-Hill/Irwin, New York. 914 p. Available at: [Link]

16.Hrinshikesh, Ch., Srijit, Ch. (1997). Management accounting. IASE University. Available at: [Link]

17.Jae K. Shim (1998). Theory and problem of financial management $2^{\text {nd }}$ Ed. Schaum's outline of financial management. McGraw-Hill. 518 p. Available at: [Link]

18.Joshi, P., Al-Mudahaki, J., \& Bremser, W. (2003). Corporate budget planning, control and performance evaluation in Bahrain. Managerial Auditing Journal, 18(9), 737-750. [Google Scholar] [CrossRef]

19.Joye M.P., Blayney P.I. (1990). Cost and Management accounting practices in Australian manufacturing companies; survey results. Sydney: The Accounting and Finance Foundation, University of Sydney. Available at: [Link]

20.Kiringai, J. (2002). Budget Reforms and Medium-term expenditure framework in Kenya, KIPPRA, working, Nairobi. Nairobi: Kenya Institute for Public policy, Research and Analysis. Available at: [Link]

21.Kotler, P. (1997). Marketing Management, Planning, Implementation, and Control, $9^{\text {th }}$ edition. Available at: [Link]

22.Needles, A., Caldwell, F. (1994). Financial and managerial accounting. $3^{\text {rd }}$ Ed. Florida University. 1488 p. Available at: [Link]

23.Negera, G. (2006). Analysis of Medium Term Expenditure Planning and Budget Allocation in Ethiopia. MA Thesis, Addis Ababa University, Addis Ababa Ethiopia. [Google Scholar]

24.Olurankinse, F. (2013). Poor budgetary performance: causes and implications for development. European Journal of Accounting Auditing and Finance Research, 1(2), 53-66. Available at: [Link]

25.Spes, N. (2014). An assessment of budget preparation and monitoring process. Addis Ababa State University. [Google Scholar]

26.Surajkumar, P. (2011). A Study of "Budgetary Control System as a Tool of Finance Control” Need and Importance. Available at: [Link]

27.Tadesse, G. (2013). Assessment of budget preparation, utilization and budget performance: the case of Addis Ababa mass media agency, Ethiopia. Senior research paper. ST. Mary's University College. Addis Ababa. Available at: [Link]

28.Thomas, K. (1974). Power in the resource allocation process; the impact of rational systems. Journal of Higher Education Policy and Management, 22, 127-137. [Google Scholar] [CrossRef]

29. Yayu Wereda Finance Office In Ilu Aba Bor Zone (2011/012E.C). Annual and quarter Reports. Available at: [Link]

30.Turyakina, N. (2004). Pricing, budget management and performance. Uganda: Makerere University. Available at: [Link] 